\title{
LORD ATKIN OF ABERDOVEY
}

\section{H. C. Gutteridge}

THE death of Lord Atkin has deprived our English law schools of 1 one of their staunchest friends, and will be deeply deplored by all who have the cause of legal education at heart. The teaching and the study of the law meant much more to him than a mere preparation for professional life, for the law was 'all the time the object of his fervent and almost passionate devotion,' ${ }^{1}$ and he was unswerving in his insistence that it should have the place due to it in the studium generale which connotes the unity of knowledge. The full extent of the services which he rendered to legal education will probably never be known, because he was not given to seek publicity for his opinions or his achievements, but it is largely due to his zeal and enthusiasm that our law schools now occupy a very different position from that held by them a quarter of a century ago. His influence made itself felt in two directions. The improvement in the status of law teachers is in no small measure the result of his efforts on their behalf, and he also played a leading part in securing the establishment of closer contact between the academic and practising sides of the law.

The first part of the Report of the Legal Education Committee, 1934, which was drafted by him, contains an expression of his views on the future of legal education in England. He regarded it as essential to maintain the co-existence of the professional and the academic law schools, because he felt, in the first place, that the professional bodies satisfied a need which could not be met by the law faculties, since there is-and always will be-a type of student who for one reason or another cannot take advantage of the facilities offered by the universities. Further, there was, in his opinion, justification for the diversion of legal studies into those which emphasize the practical side, and those which stress the scientific or cultural aspects of the law, though he urged that care should be taken not to exaggerate this distinction which must be confined within its proper limits. Holding these views he was a strong supporter of the policy which would endeavour to abolish or minimise the duplication and overlapping of instruction, and to assign to each type of law school that sphere of legal training for which it is best fitted. If full effect could have been given to this policy a great step in advance would have resulted, but this has not proved to be possible for certain reasons which cannot be discussed here. Some degree of success has, however, been attained in the increased recognition given by the profession to the law examinations of the universities. It may be added that Lord Atkin was also convinced of

1 Lord Wright in the Iaw Quarterly Review, October, 1944. 
the value of a legal education quite apart from any qualification for practice which it might confer, a belief which is supported by the recent growth in numbers of students who take law as their subject, but have no intention of devoting themselves to a professional career.

Many of us will treasure the memory of Lord Atkin, not only as a great master of the common law, but also as one whose constant endeavour it was to ensure that the duty of training the lawyers of the future should be regarded as one of the most important and honourable tasks which may fall to the lot of a member of our profession. 